\author{
Sławomir MICHALAK ${ }^{1}$ \\ Jerzy BOROWSKI ${ }^{2}$ \\ Andrzej SZELMANOWSKI ${ }^{3}$
}

\title{
WYBRANE PROBLEMY BADAŃ NAHEŁMOWEGO SYSTEMU WYŚWIETLANIA PARAMETRÓW LOTU SWPL-1 CYKLOP
}

\begin{abstract}
W opracowaniu przedstawiono zakres i wybrane problemy badań nahełmowego systemu wyświetlania parametrów lotu SWPL-1 Cyklop. Zaprezentowany system współpracuje z wieloma pokładowymi układami i głównie z nich uzyskuje informację o parametrach lotu podlegających zobrazowaniu. Informacja do systemu jest przekazywana w postaci sygnałów analogowych oraz sygnałów binarnych. W układzie dopasowania sygnałów następuje standaryzacja sygnałów do postaci akceptowanej przez komputery graficzne. Badania zostały przeprowadzone w czasie wdrożenia wymienionego systemu na śmigłowcu Mi-17. Badania obejmują zakres wykonany przez producenta systemu, akredytowane laboratorium oraz zespół badawczy z udziałem przedstawicieli użytkownika. Obejmują one badania istotnych parametrów wyszczególnionych w wymaganiach użytkownika systemu. Wykonano zarówno badania naziemne, jak i badania w locie. Śmigłowiec Mi-17 z zabudowanym systemem przeszedł pomyślnie wszystkie etapy badań; nahełmowy system wyświetlania parametrów lotu SWPL-1 Cyklop został wdrożony do eksploatacji.
\end{abstract}

Słowa kluczowe: system celowniczy, śmigłowiec, badania w locie

\section{Wprowadzenie}

System wyświetlania parametrów lotu SWPL-1 jest przeznaczony dla śmigłowców: Mi-17-1V, Mi-17 T/U, Mi-17 AE oraz innych wersji śmigłowca Mi-17. System odbiera i przetwarza informacje z systemów pokładowych śmigłowca oraz przekazuje je do wyświetlaczy nahełmowych w postaci symboli graficznych lub w postaci cyfrowej. System jest przeznaczony dla załóg śmigłowca Mi-17 w celu umożliwienia załodze prowadzenia obserwacji terenu przy jednoczesnej kontroli parametrów lotu śmigłowca. System wizualizuje parame-

\footnotetext{
${ }^{1}$ Autor do korespondencji/corresponding author: Sławomir Michalak, Instytut Techniczny Wojsk Lotniczych, ul. Księcia Bolesława 6, 01-494 Warszawa, tel.: (22) 6851443, e-mail: slawomir.michalak@itwl.pl

2 Jerzy Borowski, e-mail: jerzy.borowski@itwl.pl

3 Andrzej Szelmanowski, e-mail: Andrzej.szelmanowski@itwl.pl
} 
try lotu dla dowódcy załogi - I pilota oraz II pilota, niezbędne do realizacji misji bojowej śmigłowca. System można wykorzystywać w warunkach dziennych i nocnych. W lotach dziennych, bez względu na naturalne warunki oświetlenia, system pracuje z dziennym wyświetlaczem nahełmowym DWN-1. W lotach nocnych z wykorzystaniem gogli noktowizyjnych PNL-3 system pracuje z nocnym wyświetlaczem nahełmowym NWN-1 w każdych warunkach oświetlenia zewnętrznego, przy których możliwe jest wykorzystanie gogli.

\section{Obiekt badań}

Obiektem badań był system wyświetlania parametrów lotu SWPL-1 Cyklop dla śmigłowców Mi-17, którego schemat blokowy przedstawiono na rys. 1. Zaprezentowany system współpracuje $\mathrm{z}$ wieloma pokładowymi układami i głównie z nich uzyskuje informację o parametrach lotu podlegających zobrazowaniu. Informacja do systemu SWPL-1 Cyklop jest przekazywana w postaci sygnałów analogowych oraz sygnałów binarnych. W układzie dopasowania sygnałów UDS-1 następuje standaryzacja sygnałów do postaci akceptowanej przez komputery graficzne KG-1. W układzie tym następuje również rozdzielenie sygnałów na dwa niezależne tory zobrazowania informacji dla I i II pilota. Komputery graficzne KG-1, na podstawie informacji dostarczanej przez układ UDS-1, odbiornik GPS-155XL oraz centralę ADU-3200, wypracowują informację do zobrazowania w dziennym wyświetlaczu nahełmowym DWN-1 lub nocnym wyświetlaczu nahełmowym NWN-1. Informacja z GPS-155XL oraz centrali ADU3200 jest przekazywana do komputerów graficznych z wykorzystaniem szyny ARING-429. Wyświetlacz nahełmowy jest typu przeziernego, tzn. pilot widzi bez zniekształceń otoczenie, a zobrazowanie parametrów lotu jest rzutowane na siatkówkę oka w układzie optycznym, gdzie pozorny obraz powstaje w nieskończoności. Wykonanie to zapewnia jednoczesne ostre widzenie parametrów lotu i otoczenia poza śmigłowcem, bez konieczności akomodacji oka. Dzienny wyświetlacz nahełmowy DWN-1 jest podłączany do złącza szybko rozłącznego w kabinie pilota. Do tego samego złącza jest podłączany nocny wyświetlacz nahełmowy NWN-1. W tym samym czasie jest więc możliwa praca tylko z dziennym albo z nocnym wyświetlaczem nahełmowym. System SWPL-1 jest systemem wieloprocesorowym o architekturze rozproszonej, wykorzystujący kilka standardów zarówno analogowych, jak i cyfrowych dla wzajemnej komunikacji oraz komunikacji z systemami pokładowymi śmigłowca. Posiada wielopoziomową diagnostykę $\mathrm{z}$ monitorowaniem stanu technicznego, aktywną również w czasie lotu śmigłowca.

W systemie SWPL-1 Cyklop wyświetlanych jest 16 wytypowanych parametrów pilotażowych, nawigacyjnych i pracy zespołu napędowego, które są prezentowane w postaci zarówno cyfrowej, jak i analogowej. System posiada również sygnalizację ostrzegania WARN informującą o niebezpiecznych lub granicznych stanach występujących na pokładzie śmigłowca. Uwzględniono 


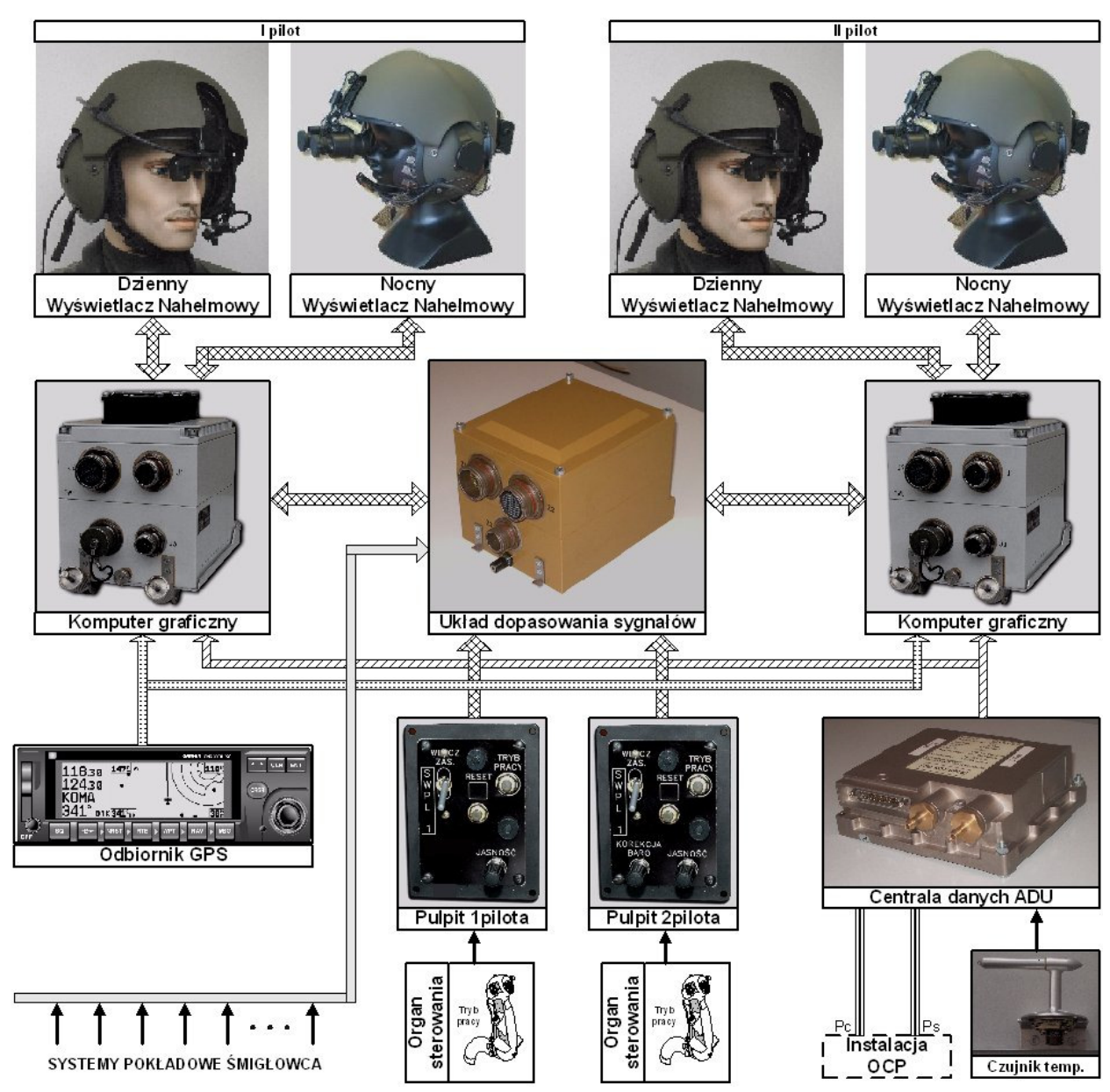

Rys.1. Schemat blokowy systemu wyświetlania parametrów lotu SWPL-1 Cyklop

Fig. 1. The block diagram of the SWPL-1 Cyklop display system of flight parameters

w niej 14 stanów sytuacji niebezpiecznych. System kontroluje również wybrane stany awaryjne i błędy pracy systemów pokładowych i informuje pilotów o tych stanach za pomocą sygnalizacji FAIL. Wyświetlanie informacji jest zorganizowane przez wybór odpowiedniego zakresu pracy: nawigacyjnego NAV, operacyjnego OPER oraz awaryjnego AWAR. System posiada funkcję swobodnego wyboru zakresu wyświetlanych informacji, definiowanego przez użytkownika na swoje potrzeby. Wybór zakresu pracy systemu (zobrazowania) oraz wygaszanie informacji o sytuacjach niebezpiecznych i błędach pracy systemów pokładowych są realizowane zgodnie z zasadą HOCAS.

Zastosowanie na pokładzie śmigłowca systemu wyświetlania parametrów lotu SWPL-1 Cyklop poprawia świadomość sytuacyjną pilotów podczas reali- 
zowania misji bojowych. Poprawia również bezpieczeństwo pilotowania śmigłowca podczas wykonywania skomplikowanych zadań. System zapewnia wizualizację pełnej informacji, niezbędnej do realizacji zadań, przy jednoczesnej obserwacji otoczenia poza kabiną śmigłowca. Istotną cechą systemu SWPL-1 jest jego odporność na oddziaływanie czynników środowiskowych. System został tak skonstruowany, aby zapewniał poprawne działanie w szerokim zakresie wartości temperatury zewnętrznej, wilgotności, narażeń mechanicznych oraz zmian ciśnienia atmosferycznego. System jest odporny na oddziaływanie kurzu i pyłu na terenach pustynnych oraz w środowisku o dużym zapyleniu $[1,2]$.

\section{Zakres wykonanych badań systemu}

Badania systemu wyświetlania parametrów lotu SWPL-1 Cyklop prowadzono na wszystkich etapach konstruowania i wdrażania do eksploatacji. Zakres badań był ściśle związany $\mathrm{z}$ wymaganiami określonymi przez użytkownika w założeniach taktyczno-technicznych. Spełnienie tych wymagań spowodowało konieczność dostosowania pierwotnej wersji konstrukcji systemu i oprogramowania do wizji systemu związanej z zadaniami wykonywanymi przez załogi śmigłowca Mi-17. Badania wykonane na systemie SWPL-1 Cyklop można przedstawić w postaci chronologicznej.

\section{Badania producenta systemu SWPL-1 Cyklop}

1. Badania konstruktorskie systemu. Badania te prowadzono na etapie konstruowania systemu. Miały one na celu sprawdzenie poprawności rozwiązań konstrukcyjnych wybranych elementów systemu oraz sprawdzenie i testowanie oprogramowania. Na tym etapie wykonano również wybrane badania bardziej odpowiedzialnych części systemu, co do których występowała niepewność konstruktora co do poprawnego działania w różnych warunkach narażeń środowiskowych.

2. Badania typu systemu. Badania wykonano w celu oceny skuteczności i celowości wniesionych zmian do konstrukcji urządzeń po otrzymaniu szczegółowych wymagań zawartych w ZTT. Pełny zakres tych badań wykonano dla sprawdzenia charakterystyk taktyczno-technicznych systemu i elementów systemu. Badania te wykonano zgodnie z Normą Obronną NO-06-A105:2005.

3. Badania niezawodnościowe. Badania niezawodnościowe prowadzono od początku wykonania pierwszego egzemplarza systemu oraz na etapie eksploatacji w komplecie zabudowanego na pokładzie śmigłowca. Badania te są w trakcie realizacji i będą prowadzone na pierwszych czterech śmigłowcach Mi-17 z zabudowanymi systemami SWPL-1. Mają one na celu weryfikację wykonanych obliczeniowo podstawowych wskaźników niezawodności systemu. 
4. Badania zdawczo-odbiorcze przed zabudową na śmigłowcu. Badania zdawczo-odbiorcze wykonuje się na każdym egzemplarzu wyprodukowanego systemu w celu sprawdzenia, czy każdy komplet systemu SWPL-1 jest zgodny z wymaganiami dokumentacji konstrukcyjnej. Badania odbioru dokonuje przedstawiciel zamawiającego $\mathrm{w}$ obecności przedstawiciela producenta $\mathrm{w}$ zakresie i kolejności przewidzianej w WT. Badania dotyczą zakresu przewidzianego przed zabudową na pokładzie śmigłowca.

5. Badania zdawczo-odbiorcze po zabudowie na śmigłowcu. Badania te wykonano, opierając się na metodyce zawartej w warunkach technicznych zabudowy systemu na pokładzie śmigłowca. Wykonano je po zakończeniu procesu technologicznego zabudowy systemu. Badania te przeprowadzono w celu sprawdzenia poprawności pracy przed przekazaniem systemu do dalszych badań przez uprawnione instytucje i organy.

\section{Badania systemu SWPL-1 Cyklop przez akredytowane laboratorium w trybie II OiB}

Badania w tym zakresie miały na celu wykazanie, że system SWPL-1 zabudowany na śmigłowcu spełnia wymagania zawarte w specyfikacji technicznej (ZTT). Badania zostały wykonane przez akredytowane laboratorium zgodnie z przepisami zawartymi w ustawie z dnia 17 listopada 2006 r. O systemie zgodności wyrobów przeznaczonych na potrzeby obronności państwa (Dz.U. 06235.1700 z późn. zm.). W ramach tych badań zostały wykonane badania naziemne i badania w locie.

\section{Badania typu śmigłowca Mi-17 z zabudowanym systemem SWPL-1 Cyklop pod nadzorem komisji}

Badania w tym zakresie były nadzorowane przez komisję badań typu, powołaną z udziałem przedstawicieli użytkownika, 15 Rejonowego Przedstawicielstwa Wojskowego, przedstawicieli zamawiającego oraz wykonawcy systemu. Badania te przeprowadzono w celu potwierdzenia bezpieczeństwa użytkowania śmigłowca $\mathrm{z}$ zabudowanym systemem. $\mathrm{W}$ ramach tych badań zrealizowano badania naziemne i badania w locie.

\section{Badania zdawczo-odbiorcze po badaniach typu dla systemu zabudowanego na śmigłowcu}

Po badaniach typu zgodnie z Normą Obronną NO-06-A105:2005 ponownie wykonano badania zdawczo-odbiorcze $\mathrm{w}$ zakresie określonym w warunkach technicznych na zabudowę systemu. Badania miały na celu potwierdzenie poprawności pracy zabudowanego systemu po wykonaniu zaleceń komisji i przed przekazaniem śmigłowca do użytkownika. 


\section{Próby zdawczo-odbiorcze z śmigłowca z zabudowanym udziałem przedstawicieli użytkownika}

Próby zdawczo-odbiorcze z zabudowanym systemem przeprowadzono bezpośrednio przed przekazaniem śmigłowca do użytkownika. Próby obejmowały m.in. lot próbny kontrolny wykonany przez pilotów w celu końcowej oceny poprawności pracy systemu SWPL-1 Cyklop zabudowanego na śmigłowcu Mi-17.

\section{Wybrane zagadnienia badań systemu}

Badania systemu wyświetlania parametrów lotu na każdym etapie wiązały się z wieloma problemami, które były rozwiązywane przez konstruktorów, programistów i zespół badawczy. W niniejszej części zostaną przedstawione wybrane problemy, które wymagały szczególnej uwagi oraz sprawiały najwięcej trudności w ich rozwiązaniu. Pierwsza część badań związana z konstruowaniem systemu jest niezmiernie ważna ze względu na dalsze skutki błędów i niedociągnięć tego etapu. Konstruowanie musi więc być szczególnie związane ze spełnieniem wymagań i metodykami badań systemu na dalszych etapach. Kwestie, które wydają się czasami mało istotne na etapie konstruowania, mogą być bardzo uciążliwe na dalszych etapach badań i powodować konieczność ingerencji w konstrukcję systemu. Błędy programowe łatwo jest wyeliminować w dalszych etapach. Wymaga to ingerencji programisty i wykonania nowej wersji oprogramowania. Błędy sprzętowe są o wiele trudniejsze do wyeliminowania i wymagają często powtórzenia badań środowiskowych lub badań kompatybilności elektromagnetycznej.

System wyświetlania parametrów lotu SWPL-1 Cyklop jest przykładem połączenia tradycyjnej technologii analogowej występującej na pokładzie śmigłowca Mi-17 z nowoczesną technologią cyfrową zawartą w samym systemie. Jednym z przykładów problematyki badawczej w tym obszarze było zapewnienie dokładności odtwarzania i powtarzalności charakterystyki statycznej toru pomiarowego wysokości rzeczywistej (z radiowysokościomierza). Okazało się, że proste metody przesyłania informacji analogowej oparte na różnych przekazach sygnału analogowego były niewystarczające. Widocznym efektem było znane zjawisko „pływania” charakterystyk oraz wrażliwość przy włączeniach znacznych obciążeń na pokładzie śmigłowca. Oczywiście znana jest zasada obowiązująca dla tego typu przypadków, polegająca na tym, że sygnał analogowy najlepiej jest przetworzyć na postać cyfrową w pobliżu źródła jego wytwarzania, jednak czasami ze względów konstrukcyjnych jest to utrudnione lub niemożliwe. Problem ten w systemie SWPL-1 Cyklop został rozwiązany przez połączenie techniki różnicowego przekazywania sygnału z dodatkowym pomiarem potencjałów mas w wybranych punktach połączenia systemu z konstrukcją śmigłowca. Osobnym utrudnieniem podczas badań dokładności odtwarzania 
charakterystyk statycznych w torach pomiarowych jest możliwość ich zaburzania przez sam pomiar. W przypadku toru pomiarowego wysokości rzeczywistej problem polegał na tym, że wytwarzany przez radiowysokościomierz sygnał analogowy był wykorzystywany na pokładzie śmigłowca przez dwa istniejące systemy i konieczne było podłączenie trzeciego systemu (toru z systemu SWPL-1 Cyklop). Podłączenie dodatkowego obciążenia wymagało znacznego zwiększenia impedancji wejściowej toru pomiarowego niż był zakładany pierwotnie.

Innym problemem, jaki wystąpił podczas badań systemu, było wyeliminowanie wrażliwości toru pomiarowego kątów pochylenia, przechylenia i kursu na zakłócenia występujące na pokładzie śmigłowca. Na pokładzie śmigłowca wymienione wielkości są mierzone z wykorzystaniem układów selsynowych. Podłączenie techniki cyfrowej do układów selsynowych wydawało się prostą operacją związaną z przetwarzaniem sygnału. Badania systemu w warunkach laboratoryjnych nie sygnalizowały występowania tego problemu. Wystąpił on dopiero po zabudowie na pokład śmigłowca. Co więcej, nie wystąpił on również podczas badań naziemnych systemu z wykorzystaniem naziemnych źródeł zasilania prądu przemiennego. Ujawnienie problemu nastąpiło dopiero po uruchomieniu zespołu napędowego. Widocznym efektem było wirowanie skal pochylenia, przechylenia i kursu w zobrazowaniu przez system. Trudność tę udało się rozwiązać przez wprowadzenie w obwody pomiarowe specjalnych filtrów w obwodach synchronizacji oraz obwodach fazy odniesienia.

Kolejnym problemem, jaki wystąpił podczas badań systemu, było spełnienie wymagań kompatybilności elektromagnetycznej. Badania systemu przeprowadzono dla następujących wymagań Normy Obronnej NO-06-A200: KCS-01, KCS-06, KCS-07, KCS-08, KRS-01, KRS-02, KCE-01, KCE-02, KRE-01, KRE-02. Największą trudnością podczas badań było spełnienie wymagań dla KCE-02 oraz KRE-02. Wymaganie KCE-02 dotyczy emisji przewodzonych na przewodach zasilających, natomiast wymaganie KRE-02 - emisji promieniowanych pochodzących od systemu, osłon podukładów i wszystkich kabli połączeniowych. Spełnienie wymagań dotyczących dopuszczalnych poziomów emisji wymaga wykonania specjalnej konstrukcji obudowy urządzeń w celu zapewnienia szczelności elektromagnetycznej. Szczelność elektromagnetyczna obudowy zabezpiecza przed emisjami promieniowanymi, pochodzącymi głównie od procesorów. Zasilacze modułów elektronicznych znajdujące się wewnątrz bloków powinny posiadać specjalne układy filtracji na wejściach i wyjściach eliminujące poziom zakłóceń, pochodzących głównie od przetwornic elektronicznych pracujących w paśmie wysokich częstotliwości. Szczególną uwagę należy zwrócić na ekranowanie wiązek przewodów zasilających i sygnałowych. Aby były spełnione wymagania dopuszczalnych poziomów emisji, konieczne było zastosowania podwójnego ekranowania. Ekrany przeciwzakłóceniowe zastosowano na pojedynczych przewodach oraz na całych wiązkach elektrycznych. Należy również pamiętać o odpowiednim połączeniu ekranów wewnętrznych, zewnętrznych 
i mas dla eliminacji tych zakłóceń. Przykładowe charakterystyki spełnienia wymagań dla KCE-02 i KRE-02 przedstawiono na rys. 2. i 3.

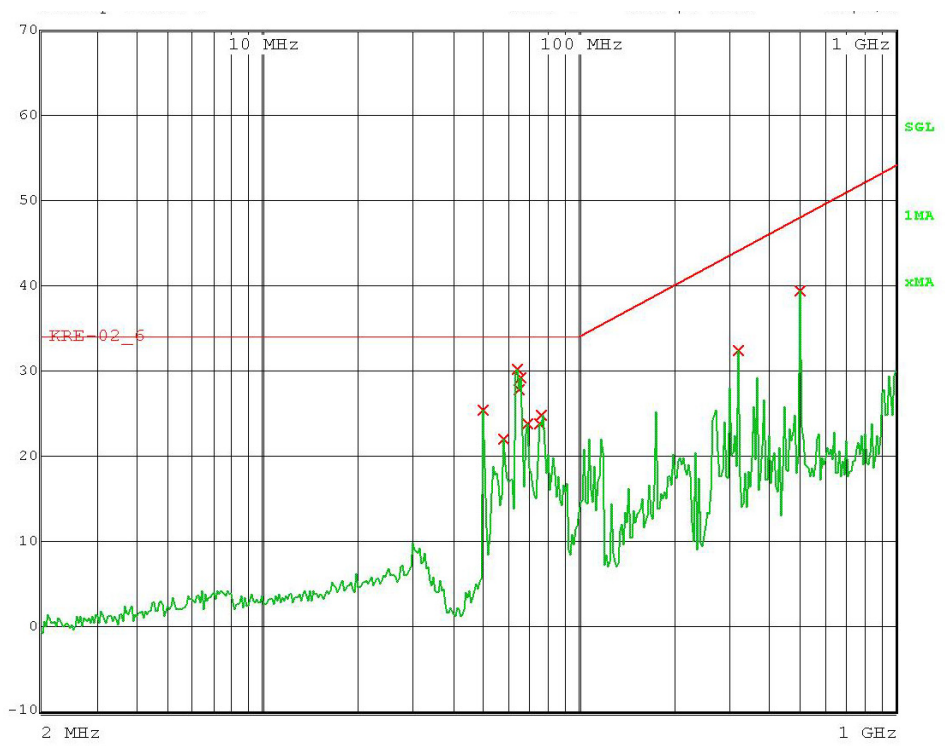

Rys. 2. Dopuszczalne według KRE-02 i rzeczywiste poziomy emisji

Fig. 2. The allowable according to KRE-02 and real emission levels

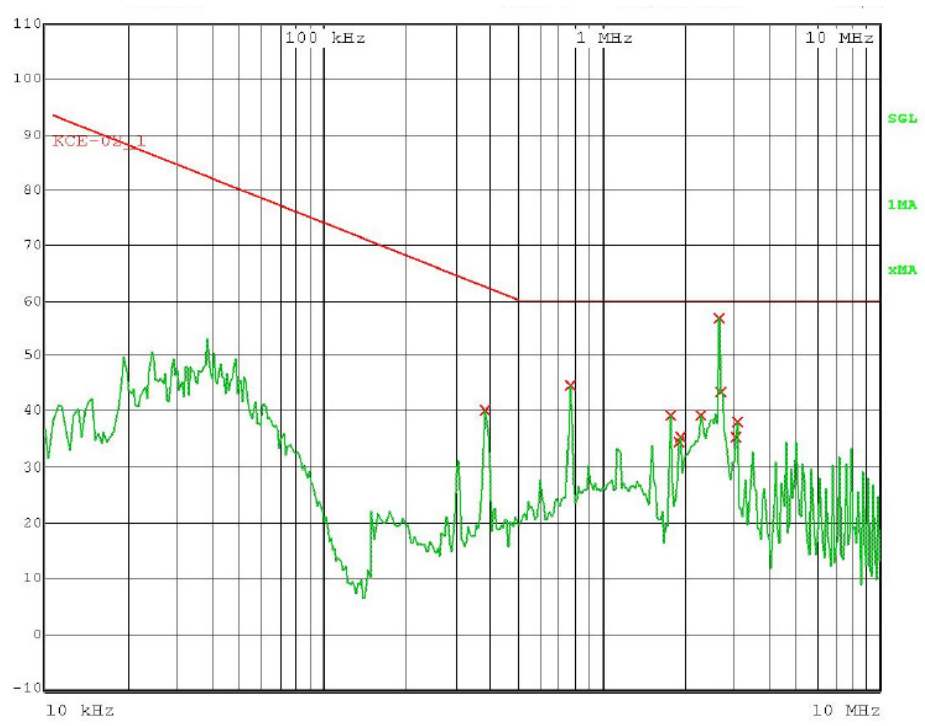

Rys. 3. Dopuszczalne według KCE-02 i rzeczywiste poziomy emisji

Fig. 3. The allowable according to KCE-02 and real emission levels 
Badania w locie (rys. 4. i 5.) systemu SWPL-1 Cyklop przeprowadzano zarówno w dzień, jak i w nocy, w różnych warunkach oświetlenia zewnętrznego. Badania przeprowadzali piloci doświadczalni. Ogólny czas lotów próbnych podczas badań wynosił ok. $80 \mathrm{~h}$. Po wykonaniu pełnego programu badań zarówno piloci, jak i komisja badań potwierdzili spełnienie wymagań zawartych w ZTT oraz bezpieczeństwo użytkowania śmigłowca z zabudowanym systemem.

Rys. 4. Obsługa przedlotowa $\mathrm{z}$ dziennym wyświetlaczem nahełmowym DWN-1

Fig. 4. Pre-flight service with day's helmet-mounted DWN-1 display

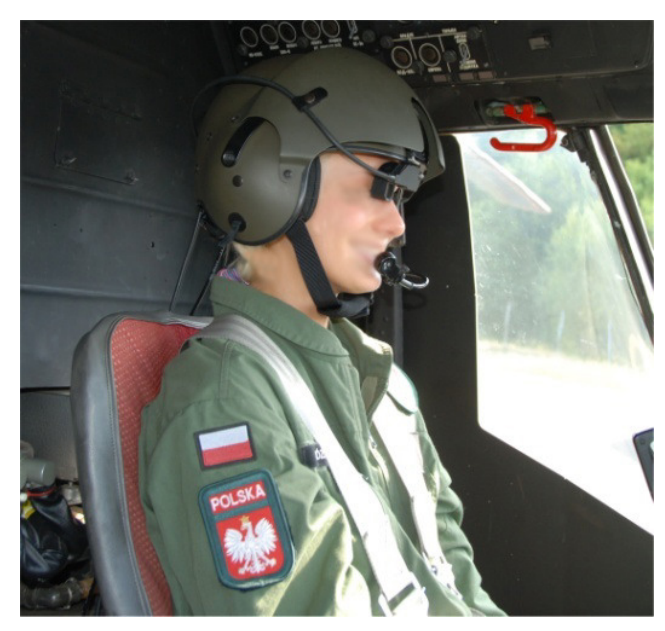

Rys. 5. Obsługa przedlotowa $\mathrm{z}$ nocnym wyświetlaczem nahełmowym NWN-1

Fig. 5. Pre-flight service with night's helmet-mounted DWN-1 display

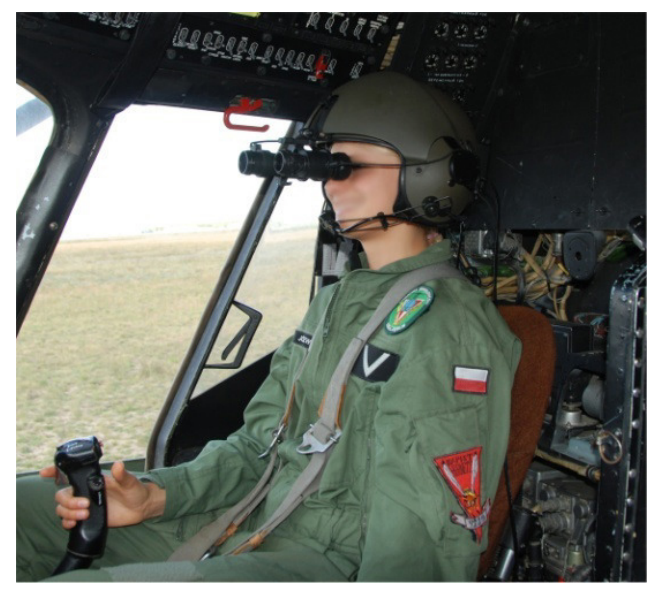

\section{Uwagi końcowe}

Wymienione problemy badań zostały pomyślnie rozwiązane oraz uwzględniono wiele dodatkowych życzeń użytkownika poprawiających właściwości ergonomiczne systemu. System wyświetlania parametrów lotu CWPL-1 Cyklop spełnia wszystkie wymagania użytkownika zawarte w założeniach taktyczno- 
-technicznych. Potwierdzenie spełnienia wymagań dokonało akredytowane laboratorium oraz komisja badań typu. System otrzymał Nagrodę Prezydenta RP na XVII Międzynarodowym Salonie Przemysłu Obronnego MSPO’ w 2009 r. System SWPL-1 Cyklop jest wdrożony do eksploatacji.

\title{
Literatura
}

[1] Borowski J., Szelmanowski A., Michalak S.: Nahełmowy system prezentacji danych - poprawa bezpieczeństwa lotniczych systemów transportowych. Logistyka, 2/2010.

[2] Michalak S., Borowski J., Szelmanowski A.: Możliwości zastosowania systemu nahełmowej prezentacji danych w modernizacji śmigłowców wojskowych. VI Konferencja Awioniki „AWIONIKA'2010”, Rzeszów-Bezmiechowa 2010.

\section{SELECTED PROBLEMS OF TESTING OF THE HELMET-MOUNTED SWPL-1 CYKLOP SYSTEMDISPLAYING FLIGHT PARAMETERS}

\begin{abstract}
A bstract
In the paper the range and some selected problems of testing of the SWPL-1 Cyklop displaying the flight parameters have been presented. Presented system cooperates with many on-board systems and allows to obtain information about the flight parameters subjected to imaging. Information is transmitted to the system in the form of analog and binary signals. Signals are standardized into form accepted by graphic computers by the signal fitting system. The tests were carried out while implementing the helmet-mounted display SWPL-1 Cyklop into the Mi-17 helicopter. The researches were focused on the testing range carried out by the manufacturer system, the accredited laboratory, and the research team, including the end user's representatives. the research scope includes the significant parameters specified in the system user requirements. Both groundbased and flight tests were carried out. At present, the Mi-17 helicopter with the SWPL-1 Cyklop system built in has successfully completed all stages of the testing work. The helmet-mounted display system SWPL-1 Cyklop has been introduced into the service.
\end{abstract}

Keywords: sight system, helicopter, flight tests

DOI:10.7862/rm.2013.27

Otrzymano/received: 15.09 .2013

Zaakceptowano/accepted: 22.10 .2013 